\title{
ASPECTS AND PROBLEMS OF THE TEMPLARS' RELIGIOUS PRESENCE IN MEDIEVAL EUROPE FROM THE TWELFTH TO THE EARLY FOURTEENTH CENTURY
}

\author{
BY JOCHEN SCHENK
}

The medieval military orders were religious institutions whose members had professed a life of combat and prayer that integrated them into a religious landscape sharply defined by diversity. And yet still very little is known about the military orders' religious functions in the dioceses in which they held ecclesiastical possessions. By focusing on one military order in particular, the Order of the Temple, this study aims to achieve two goals: first, to provide a critical overview of recent scholarship in the emerging field of military order (and especially Templar) religion, and second, to examine aspects of Templar religious involvement in medieval society in general and the reactions of senior clergymen to the Templars' religious engagement on the parish level in particular. It argues that the Templars proved very keen to expand their network of parish churches and that in so doing they proved willing to engage with the lay public on a much larger scale than has hitherto been believed.

\section{INTRODUCTION}

The medieval military orders were religious institutions whose members had professed a life of combat and prayer that, although it transcended traditional forms of regular religious life by combining contemplation with active military service, nonetheless integrated them into a religious landscape sharply defined by diversity. As part of this landscape military order communities came into regular contact with secular and regular clerics from other institutions as well as with laymen and -women who provided them with revenues and possessions, among them churches and chapels and the rights pertaining to them. Through the use of these devotional spaces, the military orders became shareholders in the spiritual economy of the regions they had entered. Unfortunately, still very little is known about the military orders' religious functions in the dioceses in which they held ecclesiastical possessions. This is in spite of the fact that considerable headway has been made towards understanding the religious and social entanglements of military orders at the local level, on the one hand, and integrating their origins and developments more fully into the central narrative of religious reform and renovation in medieval Europe, on the other hand. ${ }^{1}$

1 On the former, see esp. Damien Carraz, L'ordre du Temple dans la basse vallée du Rhône (1124-1312): Ordres militaires; Croisades et societies méridionales (Lyon, 2005); Philippe Josserand, Église et pouvoir dans la peninsula ibérique: Les ordres militaires dans le royaume de 
However, what has been neglected in the debate on military order religion is a more focused discussion of how the religion of individual military orders was understood and experienced by outsiders through the ecclesiastical property these orders possessed and the devotional spaces they created and maintained. ${ }^{2}$ Recent research by Jean-Marie Allard on Templar parishes in Aquitaine, by Damien Carraz on the struggle between military orders and secular clergy over control of churches and cemeteries in Provence, and by Thomas Krämer on conflict resolution between military orders and prelates more broadly, has offered valuable insights into how such a discussion should be pursued. ${ }^{3}$ Focusing solely on the Order of the Temple, this study follows their lead by examining aspects of Templar religious involvement in medieval society in general and the reactions of senior clergymen to the Templars' religious engagement on the parish level in particular. Drawing on evidence from continental Europe (mostly from France) and the British Isles, it argues that the Templars proved very keen to expand their network of parish churches even against the wishes of bishops who previously had supported them and that, in so doing, they proved willing to engage with the lay public on an even larger scale than has hitherto been believed. ${ }^{4}$

Castille (1252-1369) (Madrid, 2004); Jochen Schenk, Templar Families: Landowning Families and the Order of the Temple in France, c. 1120-1307 (Cambridge, 2012); and Dominic Selwood, Knights of the Cloister: Templars and Hospitallers in Central-Southern Occitania 1100-1300 (Woodbridge, 1999). On the latter, see, e.g., Tom Licence, "The Templars and the Hospitallers, Christ and the Saints," Crusades 4 (2005): 39-57; idem, "The Military Orders as Monastic Orders," Crusades 5 (2006): 39-53; Jonathan Riley-Smith, Templars and Hospitallers as Professed Religious in the Holy Land (Notre Dame, 2010); and the relevant entries in Prier et Combattre: Dictionnaire européen des ordres militaires au Moyen Âge, ed. Nicole Bériou and Philippe Josserand (Paris, 2009). Although outdated, Hans Prutz, Die geistlichen Ritterorden: Ihre Stellung zur kirchlichen, politischen, gesellschaftlichen und wirtschaftlichen Entwicklung des Mittelalters (Berlin, 1908) is still useful.

2 Carlos de Ayala Martínez, "Espiritualidad y práctica religiosa entre las órdenes militares: Los orígenes de la espritualidad militaria," in As Ordens Militares: Freires, Guerreiros, Cavaleiros, ed. Isabel Christina F. Fernandes, 2 vols. (Palmela, 2012), 1:139-72, which discusses recent scholarly developments in military order religious history, has little to report about the military orders' use of churches, their pastoral work, and their relationships with local clergy (see esp. 148-54).

3 Damien Carraz, "Églises et cimitières des ordres militaires: Contrôle des lieux sacrés et dominium ecclésiastique en Provence (XIIe-XIIIe siècle)," in Lieux sacrés et espace ecclésial (IXe-XVe siècle), ed. Julien Théry, Cahiers de Fanjeaux 46 (Toulouse, 2011), 277-312; Jean-Marie Allard, "Le contrôle des paroisses, un enjeu entre les orders militaires et l'épiscopat: Le cas aquitain," in Les ordres religieux militaires dans le Midi (XIIe-XIVe siècle), ed. Nicholas Buchheit, Cahiers de Fanjeaux 41 (Toulouse, 2006), 21-52; Thomas Krämer, Dämonen, Prälaten und gottlose Menschen: Konflikte und ihre Beilegung im Umfeld der geistlichen Ritterorden, Vita regularis: Ordnungen und Deutungen religiösen Lebens im Mittelalter, Abhandlungen 64 (Berlin, 2015).

4 For additional evidence that Templar communities opened their doors to the public and engaged in charitable activities see, e.g., Malcolm Barber, "The Charitable and Medical 


\section{Templar Ecclesiastical Property}

The Templar charters that still survive in local archives and published document collections are the best source we have for information about the great number of churches, chapels, and oratories that the Templars had been accumulating since the $1120 \mathrm{~s} .{ }^{5}$ For the most part these had been donations by ecclesiastics or wealthy laymen who had given them to the Templars as sources of revenue. ${ }^{6}$ In 1139, the bull Omne datum optimum granted the Order papal permission to build new oratories for the benefit of the souls of its brethren and lay associates. ${ }^{7}$ In theory, this should have allowed every Templar community access to a chapel or church where the canonical hours could be observed. Over time the Templars established a recognizable religious presence in the regions they had entered. This would not have gone unnoticed. The Templars' ringing of church bells, for example on Maundy Thursday at every canonical hour from matins until mass and then again at Easter Eve,${ }^{8}$ alerted those living in the vicinity of the liturgical activity that went on behind commandery walls, as did of course the very sight of a Templar church or chapel and the border stones bearing the order's insignia, which the Templars and other orders used to delineate their property. ${ }^{9}$ Some of the churches that were given to the Templars became nuclei of new commanderies, as was the case, for example, with La Trinité in Reims, which Archbishop Henry of Reims had given to the Templars sometime in the late 1160 s and which became the center of a large Templar community. ${ }^{10}$ If they already had parochial status,

Activities of the Hospitallers and Templars," in A History of Pastoral Care, ed. Gillian R. Evans (London and New York, 2000), 148-68; Alan J. Forey, "The Charitable Activities of the Templars," Viator 34 (2003): 109-41; and Helen J. Nicholson, "Relations between Houses of the Order of the Temple in Britain and Their Local Communities, as Indicated during the Trial of the Templars, 1307-1312," in Knighthoods of Christ: Essays on the History of the Crusades and the Knights Templar Presented to Malcolm Barber, ed. Norman Housley (Aldershot, 2007), 195-207.

5 The earliest extant charter documenting a donation to the Templars dates to 1124. See Cartulaire général de l'Ordre du Temple 1119?-1150: Recueil des chartes et des bulles relatives à 1'ordre du Temple, ed. Marquis d'Albon (Paris, 1913), 1-2, no. 2.

6 For example, in 1156 the knight Arramonat de Espel gave the "gleysa del Castel de Cahens e las deimas e las dimicias totas autres dreyturas que a la gleysa apartenen to Dis e a madona sancta Maria de Montsaunés de la Orde de la cavaleria del Temple de Ierusalem." Antoine Du Bourg, Histoire du grand-prieuré de Toulouse (Toulouse, 1883), xxvi, no. 37 (1156).

7 Papsturkunden für Templer und Johanniter, ed. Rudolf Hiestand, Vorarbeiten zum Oriens Pontificus, Abhandlungen der Akademie der Wissenschaften in Göttingen 77 (Göttingen, 1972), 204-10, no. 3.

8 La Règle du Temple, ed. Henri de Curzon (Paris, 1886), §346.

9 Carraz, "Églises et cimitières," 280-82.

10 Obituaire de la commanderie du Temple de Reims, ed. Edouard de Barthélemy, Mélanges historiques: Choix de documents 4 (1881), 301-36. The best analysis of BNF lat. 15054, of which the obituary forms a part, is Michael J. Peixoto, "Maintaining the Past, Securing the Future in the Obituary of the Temple of Reims," Viator 45 (2014): 211-35. 
these converted churches could continue to care for the souls of parishioners. The Templar church of Montsaunès at the foot of the French Pyrenees, for example, was situated within the enclosure of a commandery but still accessible to the public. Situated on the west wall of the commandery and facing eastward, the church of Montsaunès formed a barrier between the domestic and military offices to the north and the cemetery and presbytery garden to the south. Serving the parish as well as the Order, it had two doors through which Templars and parishioners entered the church separately. Public access was through a Roman portal in the west wall of the building, which was framed by a line of mysterious heads and topped with an encircled chi-rho symbol held up by two angels. The Templars entered through a door in the north wall. Once inside the church the parishioners could marvel at colorful frescoes on the walls and a ceiling covered with stars and Templar crosses. ${ }^{11}$ The chapel in the compound of the Templar commandery of Sainte-Catherine at Montbellet in the Mâconnais also seems to have served as a parish church, in this case for the villages of Mercey and Montbellet. Built in the late thirteenth century it was decorated with gothic sculptures (including the Agnus Dei found in so many other Templar churches and on Templar seals) ${ }^{12}$ and early fourteenth-century life-size frescoes representative of the saints and apostles. ${ }^{13}$ In general, however, the Order's conventual chapels were reserved for the devotional use of Templar brothers, although laymen could still enter them. ${ }^{14}$ In fact, laymen and -women were frequently required to access the devotional spaces of commandery chapels to discuss and negotiate contracts, conclude and sign benefactions to and business transactions with the Order, or attend important ceremonies, like burials and receptions.

Burials were public affairs, and friends and relatives of the deceased flocked to Templar churches to celebrate the divine office and mourn the dead. The same holds true for burials of Templar brothers, including benefactors who had accepted the habit on their deathbed. These were celebrated by the entire Templar convent, but outsiders were allowed to attend and participate in the

11 F. Laborde, "L'église des Templiers de Montsaunès (Haute-Garonne)," Revue de Comminges 92 and 93 (1979/1980): 355-73 and 37-51.

12 E.g., Inventaire des sceaux de la Normandie, ed. Germain Demay (Paris, 1881), 351, no. 3116 (seal of Fr. Robert Pajart, preceptor of Normandy, with Agnus Dei on the right, 1260); The Victoria County History of London, ed. William Page, vol. 1, London within the Bars, Westminster and Southwark (London, 1909), 491 (seal of Fr. Robert de Saunford with Agnus Dei on the right).

13 Marc Thibout, "À propos des peintures murales de la chapelle Sainte-Cathérine de Montbellet (Saône-et-Loire)," Bulletin monumental 108 (1950): 85-89; Gabriel Jeanton, "Les commanderies du Temple Sainte-Catherine de Montbellet et de Rougepont," Annales de l'académie de Mâcon, 3rd ser., 20 (1916-17): 54-190, at 74, 79-80.

14 Alain Demurger, Les templiers: Une chevalerie chrétienne au moyen âge (Paris, 2005), 167. 
celebration. Depending on the social standing of the deceased and his family, the number of attendees varied from very few people to large crowds, as has been attested for late thirteenth-century England. Whereas the burial of Brother Thomas of Oseney near Warwick was attended only by the chaplain of the local parish church and two laymen from the same parish (a certain Adam and Richard the Miller), the burials of Brothers Robert the Carpenter and W. Marshal at Cressing apparently attracted more than sixty mourners, including "many ... secular people, both from the family and others." 15 And allegedly up to one hundred mourners attended Templar burials in the Templar infirmary at Eagle in Lincolnshire. ${ }^{16}$

The presence of family members during the burial ceremony was encouraged by the Templars, for whom such events were good opportunities to have the benefactions of the deceased reenacted and confirmed by his relatives and before witnesses. In a charter issued late in 1197, Lord Odo of Grancey remembered that when his grandfather, who had joined the Templar order late in his life, died at the nearby commandery of Bure in 1197,

the mourning brothers [of the Temple] sent for me, Odo, lord of Grancey. I, who was myself in much sorrow about the demise of my grandfather, went to Bure with my uncles Peter, Pons, and Hugh, and with many others. We remained there for as long as the ceremony of the divine office lasted. After the celebration of the divine office we proceeded to the tomb, and with great honour was the body of my grandfather buried. ${ }^{17}$

The exact location of Odo of Grancey's tomb in the devotional topography of the commandery of Bure cannot be established from the charter, but similar examples drawn from other regions show that the tombs of important benefactors-turnedTemplar were sometimes prominently placed before the altar in the commandery chapel, thus providing the families with extra incentive for further patronage as well as a focal point for future commemoration. ${ }^{18}$

15 Oxford, Bodleian Library, MS Bodley 454, fol. 82v, now edited in The Proceedings against the Templars in the British Isles, ed. Helen Nicholson, vol. 1, The Latin Edition (Farnham, 2011), 166 (see vol. 2, The Translation [Farnham, 2011], 161, for the translation).

16 Oxford, Bodleian Library, MS Bodley 454, fol. 83r, now edited in Nicholson, Proceedings, 1:160-61 (and 2:159-60 for the translation).

17 Archives départementales de Côte-d'Or, 111 H 1161/1 (dossier Montenailles) (1197 and vidimus 1276, separate charter) and 111 H 1156, no. 1 (1276). See also Ernest Petit, Histoire des ducs de Bourgogne de la race capétienne, 9 vols. (Paris, 1885-1905), 3:321-23, no. 881 (1197).

18 This was the case, for example, for the tomb of Gerard de Villers, founding benefactor of Templar Villers, which, depicting him in the habit of the Order with his hand on his sword, was prominently placed in front of the altar in the chapel of Villers. Jules Chestret de Haneffe, "L'ordre du Temple dans l'ancien diocèse de Liége ou la Belgique orientale," Compte rendu des 
If funerals attracted crowds to Templar churches, so too did receptions. During his deposition after his arrest in 1307, brother Reginald remembered that, during his reception into the Order at Provins, crowds of relatives, friends, and other people were gathering outside the closed door of the chapel. ${ }^{19}$ Perhaps as many as one hundred spectators, but among them only two Templars, had allegedly been present when William Raven was received into the Order in the chapel of Temple Combe, although it is likely that most of them would again have waited outside, since the receptions were supposed to be held in private. ${ }^{20}$ The reception of a friend or relative may not always have been the only reason why lay people flocked to Templar houses on particular occasions. Since many receptions took place during Palm Sunday, Candlemas, Easter, the Ascension, Pentecost, the Assumption, All Saints, Christmas, or the Exaltation of the Holy Cross - on feast days, in other words, which were celebrated in the Temple with a solemn procession after Mass - it is possible that some spectators, and in particular those ominous "other people," were drawn to the chapels by the spectacle of Templar devotion. ${ }^{21} \mathrm{I}$ have argued elsewhere that the Holy Cross played a particularly important role in Templar devotion. ${ }^{22}$ Its link with the Templars, who imitated Christ in their suffering and conquered evil in death, was not lost to the laity. Pious men and women flocked to the Templar church in Paris on Good Friday to witness the brothers' veneration of the Cross. Even almost twenty years after the Order of the Temple had been disbanded, the citizens of Pavia on Good Friday held on to the tradition of proceeding to the old Templar church after Mass at the Franciscan convent. ${ }^{23}$

séances de la commission royale d'histoire de Belgique 70 (1901): 297-348, at 312-13. See also (for the tomb) Simon Pierre Ernst, Tableau historique et chronologique des suffragans ou coévêques de Liège, pour servir à l'histoire ecclésiastique de ce pays (Liège, 1806), 99-100.

19 "Multis parentibus et amicis suis et quam pluribus aliis existentibus et expectionibus ad ostia dicte capelle et circa ipsam capellam que clausa erat." Le procès des templiers, ed. Jules Michelet, 2 vols. (Paris, 1841; repr. 1987), 2:355.

20 Oxford, Bodleian Library, Bodley MS 454, fol. 11v, edited in Nicholson, Proceedings, 1:20. See also Evelyn Lord, The Knights Templar in Britain (Harlow, 2001), 195; and The Victoria County History of the County of Cambridge and the Isle of Ely, ed. Louis Francis Salzman, Ralph Bernard Pugh, and John P. C. Roach, 4 vols. (London, 1938-60), 2:263.

21 For example, Michelet, Procès, 2:1 (Exaltation of the Holy Cross), 92, 136, 156, 161, 292 (on/around Pentecost), 70, 89, 97, 141, 229, 468 (on/around Ascension), 64, 100, 104, 190, 211, 263, 265, 296, 352, 358, 360, 380, 385, 392, 402, 418 (on/around Christmas).

22 Jochen Schenk, "The Cult of the Cross in the Order of the Temple," in As Ordens Militares (n. 2 above), 207-19.

23 "Procedunt autem tunc mulieres omnes velato capite, depositis ornamentis vel occulatis: visitant illa die loca indulgentiarum devotius et copiosius solito et specialiter loca Hospitalariorum seu Templariorum, nec non ecclesiam Sancti Sepulcri, ubi est similitudo et forma sepulcri Domini, procedentes illuc tota nocte precedenti, licet distet ab urbe per mille passus." Opicino de Canistris [Anonymus Ticinensis], Liber de laudibus civitatis 


\section{Templar Clergy and Religious Privileges}

However, it was the parish church under Templar patronage and not the Templar commandery chapel that provided the setting in which most laymen would have been able to witness and experience the mass celebrated by a Templar priest or, more frequently, by one of the Order's many associated priests. ${ }^{24}$ Until 1139, when the Order of the Temple was allowed its own clergy, the Templars were entitled to control the revenues of their churches and to give them as benefices to priests who needed to be accepted by the bishop and who would serve the Order temporarily. If their employment was in the Holy Land then these priests were subject to the patriarch of Jerusalem; ${ }^{25}$ otherwise, they answered to the local bishop. Only after 1139 could the Templars present their own priests - priests, in other words, who were also fully professed members of the order - to the benefices of their churches, still pending, however, the bishop's approval. ${ }^{26}$ Ideally, the bishop's approval of the Templars' candidates should have been a formality, but in reality the Templars' choices were frequently contested, causing the popes time and again to urge the bishops to accept the priests or vicars presented to them by the Templars. ${ }^{27}$ For their part, the Templars were growing increasingly reluctant to seek the bishops' approval in the first place. Still in 1235 Pope Gregory IX had to remind them to present their

ticinensis, ed. Rodolfo Maiocchi and Ferruccino Quintavalle, RIS, n.s., (Città di Castello, 1903), vol. 11, pt. 1:41 (ca. 1330).

${ }^{24}$ It is difficult to give concrete figures, but it has been estimated that in the dioceses of Périgueux, Sarlat, Bazaz, and Bordeaux, for example, about eighty-five percent of the Order's churches had, or would eventually obtain, parochial status. Allard, "Le contrôle des paroisses" (n. 3 above), 33.

25 See Gustav Schnürer, "Zur ersten Organisation der Templer," Historisches Jahrbuch 32 (1911): 298-316 and 511-61, at 515 (subjection of priests to the patriarch of Jerusalem).

26 For the role and functions of priests in the Order of the Temple, see now Christian Vogel, Das Recht der Templer: Ausgewählte Aspekte des Templerrechts unter besonderer Berücksichtigung der Statutenhandschriften aus Paris, Rom, Baltimore und Barcelona, Vita regularis: Ordnungen und Deutungen religiösen Lebens im Mittelalter, Abhandlungen 33 (Berlin, 2007), 175-84. See also Giles Constable, "Monasteries, Rural Churches and the cura animarum in the Early Middle Ages," Settimane di studio del centro italiano de studi sull'alto medioevo 28 (1982 for 1980): 349-95, at 349 and 384; and Michel Parisse, "Le redressement du clergé séculier," in Histoire du Christianisme, vol. 5, Apogée de la papauté et expansion de la chrétianité: Histoire du Christianisme (1054-1274), ed. Jean-Marie Mayeur et al. (Paris, 1993), 241-75, at 271.

27 Malteser Urkunden und Regesten zur Geschichte der Tempelherren und der Johanniter, ed. Hans Prutz (Munich, 1883), 45, no. 35 (1192); 46, no. 49 (1198) and no. 52 (1198); 48, no. 67 (1200) and no. 78 (1201); 50, no. 99 (1208); Hans Prutz, Entwicklung und Untergang des Tempelherrenordens (Berlin, 1888), 49. One of the "ideal cases" would be the admission of William de Bruere to the church of Sibthorpe on the presentation of the Master and of the Order of the Temple in England by the archbishop of York on 16 September 1281. York, Borthwick Institute of Historical Research, Reg. 3, fol. 179r; see The Registers of William Wickwane, Lord Archbishop of York, 1279-1285, ed. William Brown (Durham, 1907), 76, no. 249. 
priests and those "suitable secular clerics, who live with you in your houses, gather with you at your table, and sleep in your dormitory" to the bishop of the diocese "as you should" ("prout ad vos pertinet"). ${ }^{28}$

In his bull Omne datum optimum of 1139, Pope Innocent II invested the Templars with apostolic protection by placing them under direct papal authority and outside the fiscal and jurisdictional control of the bishops. The intention of the bull may have been to facilitate the Templars' access to the sacraments and the cure of souls (cura animarum) and not to diminish the influence of ordinary church authorities in the Order. Even so, after 1139 the door to exemption from episcopal jurisdiction stood open, and by the end of the pontificate of Alexander III (1159-1181) the Templars had shut it behind them. ${ }^{29}$ Amendments that were made to the Templar rule after 1139 included a general ban for confessions to nonTemplar priests (only to be revoked if no Templar chaplain was at hand) and the formal statement that even associated priests had no disciplinary authority in the Order. ${ }^{30} \mathrm{~A}$ set of papal bulls and decrees gradually enhanced the Templars' privileges until they eventually extended over entire areas rather than localities. ${ }^{31}$ They included the right to celebrate divine office and mass once a year in churches under interdict $(1144) ;{ }^{32}$ extensions to the Order's burial rights $(1166 \times 79) ; 33$ and the right of the chaplains of major Templar commanderies, or baiuliae, to absolve their brethren (1238). ${ }^{34}$ Also added was the permission for associated priests to

${ }^{28}$ Les registres de Grégoire IX: Recueil des bulles de ce pape, ed. Lucien Auvray, 4 vols. (Paris, 1896-1955), 2:139-40, no. 2728 (1235).

29 Alan Forey, The Templars in the Corona de Aragón (Oxford, 1973), 165-67 argues that Alexander III may have rewarded the Templars with total exemption for their support in his struggle against emperor and anti-pope. But no clear documentation of this maior libertas has survived, which has led Luis García-Guijarro Ramos to call its very existence, as a single written grant, into question. See Luis García-Guijarro Ramos, "Exemption in the Temple, the Hospital and the Teutonic Order: Shortcomings of the Institutional Approach," in The Military Orders, vol. 2, Welfare and Warfare, ed. Helen Nicholson (Aldershot, 1998), 289-93, at 291.

30 Curzon, La Règle du Temple (n. 8 above), §§353, 525; Prutz, Entwicklung und Untergang, 46-47. That the ban was still upheld in the mid-thirteenth century is illustrated by Pope Gregory IX's formal permission on 7 June 1238 that Templars suffering in Muslim captivity could use the Dominicans as confessors. Potthast, 1:899, no. 10615.

31 García-Guijarro Ramos, "Exemption," esp. 293, where the author argues that 1139 was only "the starting point of the maior libertas" of the Order. For the evolution of Templar exemption and authority, see Prutz, Entwicklung und Untergang, 46-57. See also Pierre Vial, "La papauté, l'exemption et l'ordre du Temple," in Papauté, monachisme et théories politiques: Le pouvoir e l'institution ecclésiale; Études d'histoire médiévale offertes à Marcel Pacaut, ed. Pierre Guichard et al., 2 vols. (Lyon, 1994), 1:173-80; and Elena Bellomo, The Templar Order in North-West Italy (Leiden, 2008), 148.

32 Hiestand, Papsturkunden (n. 7 above), 1:216-17, no. 10 (1144).

33 Forey, Aragón, 161.

34 Prutz, Entwicklung und Untergang, Appendix 1: Papstregesten, 270, no. 115 (1223). 
hear Templars' confessions, to absolve Templars, and to administer the sacraments to them, as well as the pope's permission for Templar chaplains to absolve all "people of the Order," or familiares, and to administer the sacraments to them as well (1260). ${ }^{35}$

These amendments were a major blow for the bishops and parish priests, who saw themselves deprived of revenues and important disciplinary powers. Not all bishops accepted these challenges to their authority willingly and quietly, as the number of references to litigations and disputes between bishops and cathedral chapters, on the one hand, and Templar convents, on the other hand, shows. Some, however, eventually acknowledged the Templars' entitlement to certain privileges in their dioceses, not least because they realized that the Order enjoyed widespread local support. This would seem to have been the case in 1189 when Hugh Bishop Hugh of Rodez confirmed the possessions held by the Templars of Sainte-Eulalie within the parish of Saint-George. He acknowledged their privileges and possession of churches in the diocese, dropped his accusations against them, and left them in possession of all gifts, alms, and bequests made to them by his parishioners, which ex occasione Decreti he had the right to reclaim. ${ }^{36}$

\section{Templars and Other Clergy: Aspects of Collaboration and Support}

In practice, the accumulation of privileges did not affect all Templar communities equally. Not everywhere would Templars have been willing to implement their right to have a cemetery, for which land would have to be made available and which would require them to loosen their ties with other religious communities on whose spiritual assistance they still counted. Some Templar houses continued to pay annuities to provide for the souls of brothers who were buried in another church. The Templars of Combe in Somerset, for example, agreed to pay the Augustinian prior and convent of Bruton three shillings annually for the souls of their brothers who were buried at Bruton. ${ }^{37}$ Nor did their exempt

35 Ibid., 275, no. 159 (1260) and no. 160 (1260).

36 "Ego Ugo, divina dignatione Ruthenesis episcopus, cum consensu et voluntate capituli Ruthenesi, dono et concedo et in perpetuum libere habere permitto fratribus miliciae Templi, presentibus et futuris, in manu Bernardi Eschafredi, gubernatoris ejusdem miliciae infra Ruthenense, omnia quae possident, vel ex pristina adquisitione possidere debent, in parochia Sti Georgii, vel infra terminos ejusdem. Confirmo eisdem fratribus omnia privilegia sua et ecclesias, quas in Ruthenensi episcopatu possident. Remitto et illis omnes querelas, quas adversus eos habebam, et nominatim relaxo eis quicquid ex occasione Decreti exigere poteram, de donis, vel legatis, sive helemosinis, quas parochiani mei ipsis fecerunt, vel de cetero facturi sunt.” Du Bourg, Grand-prieuré de Toulouse (n. 6 above), lxxii-iii, no. 111 (1189).

37 Two Cartularies of the Augustinian Priory of Bruton and the Cluniac Priory Montacute, ed. Henry Churchill Maxwell Lyte, Somerset Record Society 8 (London, 1894), 62, no. 253 $(1240)$. 
status prevent the Templars from creating ties of subordinate relationship with the bishops over churches and hospitals, which the latter were willing to assign to them in return for annuity payments and the assurance that their control over these properties would not be violated. In response to the bull Milites Templi of 1144, which urged churchmen to receive the Templars favorably, Bishop Ulger of Angers had ordered the prelates and clergy of his diocese "to receive with kindness and affection our brothers when they come to you, and grant them your churches for their preaching, and encourage your parishioners to open their hearts and to make very generous donations to them." With a clear reference to the bull, he continued that, "wishing to share in their blessedness and destiny, we ourselves grant that if they go to churches which are under an interdict, on their arrival, on one single day of the year, for the honor of God and of them, the bells shall be solemnly rung and the divine office be celebrated. All parishioners except those that are excommunicated will be allowed to enter those churches. And if any of these brothers wearing the emblem or the habit, or living the life should happen to die on that day, he may be given burial." 38

Although some senior clergy seem barely to have tolerated the establishment of the Templars' religious presence in their dioceses, others, like Bishop Ulger of Angers or Bishop Carlo of Turin, supported it outright. ${ }^{39}$ Temporary association with the Templars in the Holy Land became a recognized form of penance; ${ }^{40}$ even benefactions to the Temple (and the Hospital) and visits to particular Templar (and Hospitaller) churches counted as penitential exercises. ${ }^{41}$ Already in the 1120s the archbishop of Aux promised every person who gave a penny to the Temple a remittance of forty days of penance. ${ }^{42}$ Archbishop Theobald of Canterbury and later his successor Thomas Becket offered indulgences worth twenty

38 "Mandamus vobis atque rogamus et supplicamus, quatenus hos fratres nostros, cum ad vos venerint, benigne et affectuose suscipiatis, et ecclesias vestras ad predicandum eis exponatis, et corda vestrorum parochianorum ad impendendas eis eleemosinas suas largissime inclinetis... . Nos vero, cupientes participes esse eorum beatitudinis et sortis, concedimus ut, si ecclesie sint interdicte, ad quas illi tendent, in adventu eorum, semel in anno, uno die, ad honorem Dei et eorum, solemniter pulsatis signis, celebretur divinum officium in ipsis, admissis omnibus parochianis, exceptis excommunicatis. Et si qui sint fratres eorum qui signum vel habitum aut vitam eorum habeant, ea vice, si mortui sint, sepeliantur." Cartulaire général (n. 5 above), 15-16, no. 21 (1144); trans. Barber and Bate, The Templars, 131, no. 31.

39 For relations between the Templars and church institutions in northwestern Italy see Bellomo, Templar Order in Italy, 148-59, esp. 149 (for relations with the bishop of Turin).

40 Helen Nicholson, Love, War and the Grail: Templars, Hospitallers and Teutonic Knights in Medieval Epic and Romance, 1150-1500 (Leiden, 2001), 36-43.

41 For the remission of penance and the indulgence of petty sins granted to benefactors to the Temple by Innocent II and Hadrian IV, and to the Hospital by Lucius III, see Hiestand, Papsturkunden, 1:213, no. 7 (1139x43); 214-15, no. 8 (1144); 233-35, no. 27 (1155, repeated in $1157 \times 59,1162,1165,1166 \times 67,1168 \times 69,1173 \times 76,1190) ; 364$, no. 176 (1185). Further examples can be found in Forey, Aragón, 162. See also Licence, "Military Orders" (n. 1 above), 45.

42 Cartulaire général, 3-4, no. 6 (1126×30). 
days to visitors to the old Templar church of Saint Mary at Holborn, ${ }^{43}$ whereas Archbishop Roger of York rewarded them with ten days and the prayers and benefits of Saint Mary's, York. ${ }^{44}$ Pilgrims who arrived at New Temple London for the anniversary of the dedication of the church by the patriarch of Jerusalem secured themselves a remission of sixty days of penance. ${ }^{45}$ Other bishops from England, Ireland, and Plantagenet Aquitaine offered between ten and forty days indulgence for the same journey. ${ }^{46}$ Papal indulgences offered for pilgrimages to the Templars' church in Paris extended from fifteen days $(1217)^{47}$ to twenty days (1230). ${ }^{48}$ And in 1249 Pope Innocent IV offered a relaxation of forty days penance to everyone who contributed to the construction of the Templar church in Barcelona. ${ }^{49}$

Throughout the twelfth century, the bishops and cathedral chapters of Langres, Carcassonne, and Trois-Châteaux counted among the most prolific benefactors of the Templars in their dioceses, often instigating the foundation of new commanderies with their gifts of landed property, churches, and parochial

43 Records of the Templars in England in the Twelfth Century: The Inquest of 1185, ed. Beatrice A. Lees (London, 1935), 162, no. 6 (1151x61); 162-63 no. 7 (1162x70). These and the following examples are also cited in Licence, "Military Orders," 45. For Theobald, see also Keith V. Sinclair, "The Translation of the Vitas patrum, Thaïs, Antichrist, and Vision de saint Paul made for Anglo-Norman Templars: Some Neglected Literary Considerations," Speculum 72 (1997): 741-62, at 743.

44 Lees, Records, 1163-64, no. 8 (1169x81).

45 Ibid., lvii.

46 BL, Cotton MS Nero E VI, 74-93, which contains one papal bull and nineteen episcopal letters from the Cotton manuscript collection at the British Library in London recording promises of indulgences to visitors to New Temple in London. These documents were issued between 1161 and 1275 (but mostly between 1246 and 1262) by various bishops of Canterbury, York, Lincoln, London, Ely, and Rochester in England; Armagh, Leighlin, Waterford, Ossory, Ardagh, Achonry, Elphin, and Kildare, and Fordensis in Ireland; and Bordeaux in Plantagenet Aquitaine. The promulgation of New Temple in London was therefore a thoroughly English endeavor and, it seems, a well-orchestrated one at that. At New Temple the pilgrims would have been able to marvel at a great number of relics, among them the sword that killed St. Thomas Becket, the vial with the Precious Blood, and the two fragments of the True Cross set into reliquaries. I am grateful to Dr. Nicole Hamonic who first drew my attention to these entries. For a discussion of lay use of New Temple in London, see also Helen Nicholson, "At the Heart of Medieval London: The New Temple in the Middle Ages," in The Temple Church in London: History, Architecture, Art, ed. Robin Griffith-Jones and David Park (Woodbridge, 2010), 1-18.

47 Paris, Archives Nationales de France, L 239, no. 28 (11/01/1217). See also Henri de Curzon, La maison du Temple de Paris: histoire et description (Paris, 1888), Documents Annexes, 301, no. 1 .

48 Paris, Archives Nationales de France, L 241, no. 69 (10/06/1230). See also Curzon, La maison du Temple, 67.

49 Barcelona, Archivo de la Corona de Aragón, Bulas, leg. 11, doc. 49 (Francisco Miquel Rosell, Regesta de letras pontificadas del Archivo de la Corona de Aragón [Madrid, 1948], 92, no. 160). 
rights. ${ }^{50}$ Damien Carraz has argued that, in France and Italy at least, the military orders "received a warm welcome, partly because bishops expected some support with church reform and pastoral care from these novae religiones." 51 Their decision to complete the network of parishes in their dioceses with the help of the Templars therefore seems to have been a deliberate one, for they hoped that the presence of the new order would instill in their parishes a new spirit of religious fervor and diligence. Like the new monks and canons regular, the Templars were charged with the reform of religious communities that the bishops found lacking in discipline and vigor.

Evidence also exists that on a local level the Templars' spiritual worth was recognized by senior churchmen in the form of charters recording the transfer of churches and monasteries into the care of the Templars. Already in 1139 the newly appointed bishop of Périgueux, Geoffrey of Cauze, installed the Templars at Andrivaux after having expelled the monastery's previous occupants, a convent of Benedictine nuns, for irregular behavior. ${ }^{52} \mathrm{He}$ was thereby following in the footsteps of his predecessors, who had in previous years installed chapters of Augustinian canons at Saint-Astier and Saint-Jean-de-Côle and who had encouraged the creation of another Augustinian chapter at Chancelade, close to Andrivaux, and the foundation of the Cistercian abbey of Cadouin. ${ }^{53}$ A similar motivation (that is, to stimulate reform in the diocese) can be assumed to be behind the decision of the archbishop of Bordeaux in 1170 to install the Templars in the church of Saint-Pierre-de-Vaux (today Arveyres, dép. Gironde) ${ }^{54}$ or Bishop Ulger of Angers' plea for support for the Templars some years after he had helped establish no fewer than three reform convents in Anjou: the Savigniac priory of La Boissière (1131), the Tironensian priory at Asnière (1133), and the Cistercian abbey of Pontron (1134). ${ }^{55}$ Taken at face value, these twelfth-century examples

50 For Langres, see the charters transcribed in Petit, Histoire des ducs de Bourgogne (n. 17 above); for Carcassonne, see in particular Cartulaires des Templiers de Douzens, ed. Pierre Gerard and Élisabeth Magnou (Paris, 1965); for Trois-Châteaux see Cartulaire de la commanderie de Richerenches de l'Ordre du Temple (1136-1214), ed. Marquis de Ripert-Monclar (Avignon, 1907).

51 Damien Carraz, "Templars and Hospitallers in the Cities of the West and the Latin East (Twelfth to Thirteenth Centuries)," Crusades 12 (2013): 103-20, at 113.

52 BNF, coll. Périgord, vol. 33, fols. 1-2, 83r, and Allard, "Le côntrole des paroisses" (n. 3 above), 36 .

53 Muriel Laharie, "Evêques et société en Périgord du Xe au milieu du XIIe siécle," Annales du Midi 94 (1982): 360-62; Allard, "Le côntrole des paroisses," 36.

54 Bordeaux, Archives départementales de Gironde, H 3082, fol. 100; Toulouse, Archives départementales de la Haute-Garonne, H Malte Bordeaux 41, fol. 82; and Allard, "Le côntrole des paroisses," 36 .

55 La Boissière: Josèphe Chartrou, L'Anjou de 1109 à 1151: Foulque de Jerusalem et Geoffroi Plantagenêt (Paris, 1928), no. 73 (pièce justificative, no. 28). Asnières: Angers, Bibliothèque municipale, MS 863 [formerly 775], Asnières section, fols. 4r-v, printed ex apographo in 
seem to demonstrate the bishops' trust in the Templars' spiritual steadfastness, a trust that would certainly have registered with other laymen and ecclesiastics in the diocese. One pope who shared the bishops' evaluation of the Templars as spiritually steadfast and sound was Gregory IX, who in the late 1230s entrusted the Templars of Tuscany with the reform (ad melius reformandam) of the monastery of San Giustino in the diocese of Perugia, which he considered as "in spiritualibus deformatum et in temporalibus collapsum." ${ }^{56}$ His decision not only shows the spiritual value that he evidently attributed to the Order of the Temple; implicitly, it also demonstrates his conviction that the Templars of Tuscany possessed the spiritual manpower and equipment that was necessary to enforce a regimen of reform in a monastic community that had hitherto failed to live up to its religious standards.

As already suggested in Ulger's letter from 1144 cited above and illustrated by some of the examples just given, not all bishops and prelates treated the Templars with suspicion and hostility from the outset, although many more adopted this attitude in the thirteenth century. By then the Templars were pursuing an aggressive policy of religious expansion, thereby cutting many secular clerics short of their revenues. Nor were prelates in principle opposed to the idea that the Templars should engage in the cure of souls; some bishops even entrusted them with this task, thus treating them no differently from other reform orders. ${ }^{57}$ In many places, Templars were welcomed by secular and regular religious alike, who sought, or accepted, association with them. Ties between Templar and Cistercian communities were frequent, for example, in France and northern Italy. ${ }^{58}$ But ties to other (often very local) institutions also existed. Perhaps as early as October 1131 the canons of Arras offered to celebrate solemn Mass once a year for the three days of Rogation and the five days thereafter in their chapel at Ypres in honor of the Temple (which implied that the offerings would go to the Order). ${ }^{59}$ The canons of Péronne seem to have provided the Templars with annual payments from their prebends right up to the early fourteenth century (as we know from the Hospitallers' recorded attempt to claim their succession

\footnotetext{
Gallia Christiana in provincias ecclesiasticas distributa: Qua series et historia archiepiscoporum, episcoporum, et abbatum Franciae vicinarumque ditionum, ab origine Ecclesiarum ad nostra tempora deducitur, et probatur ex authenticis instrumentis ad calcem appositis, ed. Denys de Sainte-Marthe et al., 16 vols. (Paris, 1715-1865), vol. 14, Instrumenta, col. 154, no. 14. Pontron: ibid., col. 155-56, no. 15 (ex apographo).

56 Registres Grégoire IX (n. 28 above), 2:822, no. 3975 (9 December 1237) and 979, no. 4285 (24 April 1238).

57 See Giles Constable, The Reformation of the Twelfth Century (Cambridge, 1996), 233-34, for a similar treatment of the Order of Prémontré.

58 Schenk, Templar Families (n. 1 above), 85-125; Bellomo, Templar Order in Italy (n. 31 above), 154-55.

59 Cartulaire général, 31, no. 41 (after 19 Oct. 1131), and again 34-35, no. 45 (1132).
} 
to these revenues after the dissolution of the Temple). ${ }^{60}$ The Augustinian convent of Saint-Vaast in Flanders established in the 1140s a spiritual alliance with the Templars with whom the canons felt united in their ambition "to enlarge the body of our Lord Jesus Christ." An elemental part of this spiritual bond was that the Templars were henceforth commemorated in the canons' prayers. ${ }^{61}$ The Augustinians of Bruton in Somerset accepted Templars for burial and prayed for their souls. ${ }^{62}$ In 1193 Archbishop Imbert of Arles endowed the Templars of SaintGilles with the church of Saint-Pierre-de-Campublic, including all appurtenances and parochial rights, in return for an annual rent of one mark in silver. ${ }^{63}$ And still in 1211 Bishop Bertrand of Antibes enabled the Templars to have a church and cemetery in the town of Grasse. ${ }^{64}$

\section{Templars and Other Clergy: Aspects of Conflict}

Even if they were supportive of the Order, however, bishops and prelates were careful to take precautions that their own privileges would remain untouched and their interests protected. ${ }^{65}$ Templar chaplains who were allowed, or had been encouraged, to serve in parishes were entitled to a share in the parish revenues; the parishes, however, still remained under the bishop's jurisdiction, and, unless the donation charter stated otherwise, dues had to be paid to him. ${ }^{66}$ When the

60 Actes du Parlement de Paris, 1st ser., De l'an 1254 à l'an 1328, ed. Edgar Boutaric, 2 vols. (Paris, 1863-67), 2:136-37, no. 4420 (1315).

61 Cartulaire de l'Abbaye de Saint-Vaast d'Arras rédigé au XIIe siècle par Guimann, ed. Eugène van Drival (Arras, 1875), 253-54 [Cartulaire général, 153, no. 226] (1141x47).

62 Maxwell Lyte, Bruton (n. 37 above), 62, no. 253 (1240).

63 The Templars would henceforth hold the church in perpetuity "retento tamen in omnibus pleno jure pontificali et reverentia et obedientia et correctione cum plenitudine jurisdictionis Arelatensis ecclesie quam in ipsa ecclesia habere consuevit," having received promise that the monks would protect and defend the church with all means available to them by the Lord against all controversy and injury. All they asked in return was a rent of one mark in fine silver, which the Templars were to pay every year at the feast day of St. Luke, as well as the promise to pay the canons an additional eighteen denars for their annual synod. Marseille, Archives départementales des Bouches-du-Rhône, 56 H 5299 (1193) (BNF, n. a. 1. 5, fols. 305-6; and Damien Carraz, "Ordres militaires, croisades et sociétés méridionales: L'ordre du Temple dans la basse vallée du Rhône (1124-1312)," 3 vols. (PhD diss., Université de Lyon 2, 2003), 3:562-63, "Chartes de la Maison du Temple de Saint-Gilles," no. 245, which lists all extant copies and editions of this charter).

64 Nice, Archives départementales des Alpes-Maritimes, H 1507/1 (1211).

65 As illustrated in Damien Carraz, "Les ordres militaires et la ville (XIIe-début du XIVe siècle): L'exemple des commanderies urbaines de la basse vallée du Rhône," Annales du Midi 114 (2002): 276-92, at 287.

66 For a possible exception see, e.g., Lees, Records (n. 43 above), 166-67, no. 11 (ca. February 1173, donation from King Henry II): "Sciatis me donasse inperpetuam elemosinam et hac mea carta confirmasse fratribus Templi Ecclesiam Sancti Clementis que dicitur Dacorum extra Civitatem Londonie cum omnibus pertinenciis suis. Quam volo et firmiter precipio 
canons of Saint-Vaast in Flanders declared their spiritual alliance with the Templars, they provided them with land at Haden to build a chapel where the divine office could be celebrated for the brothers and their associates who had renounced the world but were otherwise adamant that in every other respect their parochial rights in Haden would remain intact. ${ }^{67}$

The situation was particularly tense in urban centers where commanderies suffered from restrictions imposed by the bishops and prelates, who were anxious to avoid spiritual competition from increasingly autonomous religious institutions within the city walls. ${ }^{68}$ The use of Templar chapels and cemeteries was to be limited to Templar brothers and associates, and in some urban centers, Arles being one of them, even the use of church bells was restricted. ${ }^{69}$ In 1152 , the archbishop of Arles granted the Templars permission to attach a cemetery to their oratory under the condition that they would not accept parishioners for burial without his permission. ${ }^{70}$ The abbot of Saint-Gilles gave the Templars exact

quod fratres Templi eandem habeant ecclesiam et teneant bene et in pace et libere et quiete et integer et honorifice cum omnibus ad eandem pertinentibus in terris et Capellis et decimis et in omnibus aliis rebus cum omnibus libertatibus et liberis consuetundinibus suis."

67 "Galterus Dei gratia abbas cenobii beati Vedasti Atrebatensis, cum fratribus sibi commissis omnibus hec legentibus vel agnoscentibus temporalibus quidem uti sed eternis frui. Quoniam vita morte, memoria oblivione, veritas impugnatur falsitate, nos contra hec tria impedimenta, utentes presentium litterarum annotazione, significamus tam futuris quam presentibus, quoniam cum fratribus nostris, militibus Templi Ierosolimitani et eorum subditis qui videlicet nequaquam, mundo abrenuntiato, militare Deo soli devoverunt, specialem societatem omnium spiritualium bonorum habemus, datis benigne et humiliter susceptis vicissim mutuis petitionibus, ut in augmentum corporis domini nostri Iesu Christi fraterno quoque auxilio magis magisque proficiamus. Illud etiam deinde notificamus quoniam iidem fratres milites, cum in fundo terre nostre, scilicet ville Hadensis, curiem unam constituere, in qua ipsi et sibi subjecti videlicet qui seculo abrenuntiassent, tam in morte vel sepultura quam in vita, perciperent divina, salvo in omnibus aliis jure nostre Hadensis parrochie. Hoc igitur eo affectu et tenore quo postulaverunt, causa Dei, sicut fratribus concessimus et chyrographo donum roborantes sigillo quoque nostro munivimus." Drival, Cartulaire Saint-Vaast, 253-54 (Cartulaire général, 153, no. 226) (1141×47).

68 The roles and functions of the military orders in urban contexts are covered in Carraz, "Templars and Hospitallers in the Cities" (n. 51 above); idem, "Les commanderies dans l'espace urbain: Templiers et Hospitaliers dans les villes de l'Occident méditerranéen (XIIe-XIIIe siècle)," Mélanges de l'École française de Rome-Moyen Âge 124 (2012): 11936; and idem, "Expériences religieuses en contexte urbain: De l'ordo monasticus aux religiones novae: le jalon monachisme militaire," in Les ordres militaires dans la ville médiévale (11001350), ed. idem (Clermont-Ferrand, 2013), 37-56.

69 Idem, L'ordre du Temple (n. 1 above), 326-27.

70 The original charter is lost, but various cartulary copies survive, one of which has been the source for BNF, n. a. 1. 7, fols. 2-3. The most recent edition of the text is Estelle Bœuf, "Le chartier de l'archevêché d'Arles (417-1202)," thèse de l'École des Chartes (Paris, 1996), no. 192 (1152), for which see also D. Carraz, Ordres militaires, croisades et sociétés méridionales (n. 63 above), vol. 3, "Chartes de la maison du Temple d'Arles," 62-63, no. 4; and idem, "Les ordres militaires," 287. 
prescriptions for the church they intended to build and explicitly prohibited them from celebrating the divine office for anyone other than themselves and their familiares. They were also to desist from administering the sacraments for anybody and from collecting oblations, tithes, or other revenues. ${ }^{71}$ In 1165 , the abbot of Saint-Etienne in Dijon vehemently opposed the Templars' construction of a chapel and cemetery next to their house in Dijon but was defeated when the Templars obtained papal permission for the construction to go ahead. In this case, however, the abbot's opposition to the Templars' building plans seems to have been not so much founded on the fear that the chapel would draw parishioners away from Saint-Etienne as on the fact that the chapel would block the canons' access to the nearest bridge over the river Ouche. A solution to that problem was found five years later when Hugh of Burgundy granted the canons permission to pierce through the city walls between the Templar house and the bridge and to have a gate inserted into the wall. ${ }^{72}$

Considering the relative autonomy of the more scattered Templar commanderies and the heavy reliance of all Templar houses on local support, it is no surprise that the Templar communities frequently and sometimes excessively overstepped their prerogatives in order to accommodate the spiritual demands of lay neighbors, benefactors, and parishioners, to the great annoyance of the local clergy. ${ }^{73}$ In October 1247, Innocent IV acknowledged that the Templars were stretching their privileges to the limit when he prohibited them and the Mendicants (and any other religious order for that matter) from continuing the administration of sacraments in the town of Mondovì, which he had put under interdict. ${ }^{74}$ Moreover, the Templars' habit of appointing priests to benefices or removing them from livings without the approval of the diocesan, as well as their frequent negligence in filling vacancies in due time, were causes of tension that, although they were being addressed at the Third Lateran Council in 1179, continued to strain relations between the Order and individual bishops throughout the thirteenth

71 Marseille, Archives départementales des Bouches-de-Rhône, 56 H 5289 (Carraz, Ordres militaires, croisades et sociétés méridionales, 491-92, no. 41) (1169). See also Carraz, "Les ordres militaires," 287.

72 César Lavirotte, "Mémoire statistique sur les établissements des Templiers et des Hospitaliers de Saint-Jean de Jérusalem en Bourgogne," Congrès archéologique de France 19 (1853): 224-91, at 240. An even better example of the restrictions that some bishops attached to their approval of new oratories, although this one affecting the Hospitallers and not the Templars, has survived in the charter collection of the bishops of Cavaillon. See LéonHonoré Labande, ed., "Les chartes de l'évêche et les évêques de Cavaillon au XIIIe siècle," Revue d'histoire de l'église de France 1 (1910): 82-104, at 83-85, no. 1 (1174).

73 The autonomy of Templar commanderies is discussed in Jonathan Riley-Smith, "The Structures of the Orders of the Temple and the Hospital in c. 1291," in The Medieval Crusade, ed. Susan J. Ridyard (Woodbridge, 2004), 125-43.

74 Les registres d'Innocent IV, ed. Élie Berger, 4 vols. (Paris, 1884-1920), 1:505, no. 3359 (12 October 1247). See also Bellomo, Templar Order in Italy (n. 31 above), 337. 
century. ${ }^{75}$ Even an admirer of the Order like Bishop Bartholomew of Cahors, who apparently felt bound to the Templars, and in particular to the Order's provincial master Raymbaud of Caron, by a "great friendship" (magna familiaritas) and "great affection" (magna affectio), was compelled to make arrangements so that his donation of churches to the Templars did not allow them to infringe on his "right to install chaplains in the aforesaid churches whenever these happen to be vacant, following the presentation by the brothers preceptors of the Temple, to whom the churches have been subjected, or on his rights of advowson [procuratio] or any of his other episcopal rights in them."76

Determined that their fiscal and pastoral interest in the churches would properly be communicated to, and understood by, Templar officials who usually came from knightly families, some prelates issued contracts with individual Templar preceptors using language that borrowed heavily from the vocabulary and protocol of feudal agreements. In May 1235, the Templar preceptor of La Cabane de Monson thus received a church from the Benedictine abbot of Conques, for which he was asked to swear obedience and fidelity to the abbot and his successors for the rest of his life. ${ }^{77}$ In allowing terminology that was loaded with secular implications of lordship and fealty to creep into the charters regulating their relations with other institutions, however, individual Templars became vulnerable to the accusation of willfully compromising their mandate of absolute obedience to the Pope and the Order. They, as well as the prelates, were also acting against the papacy's ruling, explicitly expressed in 1139, that "we prohibit and altogether forbid that any ecclesiastical or secular person should dare to demand fealties, homage, oaths, or other safeguards, which are commonly used by seculars, from the master and the brothers of this house [i.e., the Order of the Temple]." 78

As a direct consequence of the Order of the Temple's increasing autonomy, and success in accumulating church property, the issue of episcopal oversight and

75 Forey, Aragón (n. 29 above), 169-70; Prutz, Entwicklung und Untergang (n. 27 above), 49. For the relevant decrees at the Third Lateran Council, see Mansi, 22:222-23.

76 "Jure instituendi cappellanes in ecclesiis supradictis, quotiescumque contingerit eas vacare, ad presentationem fratrum Templi preceptorum, quibus erunt ecclesiae supradictae subjectae et salvis et retentis procurationibus nostris et aliis juribus episcopalibus in eisdem." Du Bourg, Histoire du grand-prieuré (n. 6 above), lxviii-ix, no. 101 (1255).

77 "Notum sit universis ... quod nos U. Dei gratia Conchen(sis) abbas, de communi fratrum nostrorum consilio ecclesiam nostram Sancti Petri de Salhagol cum omnibus juribus et pertinenciis suis tibi fratri Arnaldo de Bosco Templario preceptor Cabane domus milicie Monzonis commendamus et concedimus habendam et possidendam omnibus diebus vitae tuae quamdiu nobis et successoribus nostris obediens extiteris et fidelis. In cujus rei testimonium paratum paginam sigilli nostri numinime fecimus roborari. Actum cappellae de Livro Kl. maii anno Domini $\mathrm{M}^{\circ} \mathrm{CC}^{\circ} \mathrm{XXX}^{\circ}$ quinto." BNF, n. a. 1. 23 (La Cabane de Monson), fol. 76 (1235).

78 Hiestand, Papsturkunden, 1:204-10, no. 3 (trans. Barber and Bate, The Templars [n. 7 above], 61, no. 7). 
visitation became a cause of controversy. It raised the question of possessio and administratio of churches under Templar patronage, which the bishops were reluctant to give up. As Jean-Marie Allard has pointed out, ${ }^{79}$ the visitation records of Bertrand de Got, archbishop of Bordeaux, from 1304 and 1305 are evidence of how reluctant many religious communities, including the military orders, were to subject themselves to any form of inspection by outsiders. ${ }^{80}$ The bishop of Autun's planned visitation of the Templar church of Neuilly in April 1301 indicates that this was also the case elsewhere. The church of Neuilly was run by a rector, which, by the thirteenth century, described a priest serving a parish who, under normal circumstances, was subjected to the bishop's visitatio and correctio. ${ }^{81}$ On finding the doors of the church locked, the bishop reportedly asked

three Templars whom he found outside the church whether they held the keys to the gates or doors of the church. Their answer was yes; but when the bishop asked them to hand over the keys so the church could be opened and he could enter it and do what his office required of him, they refused to hand them over and to open the church or have it opened because if they did they would openly and publicly recognize and admit in the presence of the bishop that he possessed the rights of visitation and correction in this house and over its rector and brothers. When the mentioned Templars told him that with the consent of the brothers and sisters [fratres et sorores] of the house and by apostolic authority they had administratio and possessio of said church, the bishop replied that they had not been authorized or licensed by the apostolic see. As was well known, the rector of the house had been invested by the bishop; therefore they could not hold or have administratio or possessio of said house without the consent of the same bishop, who had in this case by no means consented to it or given his support. Upon this they replied that since the monastery of Mormant [which was by then in Templar possession] in the diocese of Langres had been given to them and their order by the

79 Allard, "Le côntrole des paroisses" (n. 3 above), 28-31.

80 Bordeaux, Archives départementales de Gironde, G 264 ("Visite de Clément V"), fols. 3-15 (early modern copy of lost original). See also J. Boucherie, Inventaire des titres que se trouverent au trésor de l'archeveché de Bordeaux, Archives historiques du département de la Gironde 23 (Bordeaux, 1883), 305-40; and David M. Bryson, "Clement V and the Road to Avignon, 1304-1309," in On the Margins of Crusading, ed. Helen L. Nicholson (Farnham, 2011), 61-74. The records also show, however, that some Templar houses did submit to episcopal visitation, which suggests that preceptors were able to make autonomous decisions and effectively embrace episcopal supervision if they felt compelled (or persuaded) to do so. As one of the anonymous reviewers has generously informed me, the Templars' parish church at Garway in Herefordshire was also subject to episcopal visitation, which led to disputes later under the Hospitallers.

81 André Vauchez, "Le tournant pastoral de l'Eglise en Occident," in Histoire du Christianisme 5 (n. 26 above), 738-66. 
Pope, the bishop had no authority over the mentioned house of Neuilly. As it was not a member of said monastery or belonged to its appurtenances, however, he [the bishop] demanded of the Templars that they would not violate or obstruct the bishop or church of Autun's enjoyment of the jurisdiction to which they were entitled in the house mentioned. They should leave the place because, as long as they remained there, he could not make free use of his right or the enjoyment of the right to which he was entitled. Because by saying that the administratio and possessio of said house was with them, when neither the one nor the other could be obtained or held by anybody - except by authority of the apostolic see - without the consent of the bishop of Autun, they had hindered the bishop and church of Autun in the employment of their right to install a rector for the management [administratio] of the estate [possessio]. When the Templars refused to accede to his request, he asked the dean, provost, and other canons of the church of Autun who had been present to help him defend the lawful possession and legal right of the church of Autun, warning them, however, not to heap blame or injustice upon the Templars nor to use excessive methods when defending the possession of the church. ${ }^{82}$

\footnotetext{
82 "In nomine Domini, amen. Anno Incarnationis ejusdem millesimo trecentesimo primo, indictione quartadecima, mense aprilis, die Martis ante festum beati Georgii pontificis, sanctissimi in Christo patris ac domini Bonifacii, divina providentia pape octavi, anno septimo, ex tenore presentis instrumenti publici notum pateat universis quod in presentia mei, notarii infrascripti, et testium subscriptorum, ad hoc vocatorum et rogatorum, cum reverendus in Christo pater ac dominus, dominus Bartholomeus, Dei gratia Eduensis episcopus, ad domum de Naylliaco, Eduensis diocesis, declinasset visitationis officium et quedam alia ad jus et possesionem et juridictionem ecclesie Eduensis spectantur exercenda, et veniens ad ecclesiam dicti loci, invenisset eam clausam, interrogavit tres templarios quos invenit ante dictam ecclesiam, utrum haberent claves portarum seu hostiorum dicte ecclesie, qui responderunt quod sit, et requisiti a dicto episcopo quod traderent claves ad aperiendum ecclesiam, ut intus posset intrare et ibidem facere quod suo officio incumbebat, eas tradere et predictam ecclesiam aperire vel aperiri facere recusarunt, licet palam et publice recognoscerent et confiterentur in presentia ejusdem episcopi ipsum episcopum habere visitationem et correctionem in domo predicta, rectore et fratribus ejusdem, et cum dicerent dicti templarii se habere administrationem et possessionem dicte domus de consensu fratrum et sororum dicte domus et auctoritate apostolica, idem episcopus respondens quod cum auctoritate vel licentia sedis apostolice non haberent, et notorium esset institutionem rectoris ejusdem domus ad ipsum episcopum pertinere, non potuerunt licite occupare vel habere administrationem vel possessionem dicte domus sine consensu ejusdem episcopi, qui in hoc minime consenserat nec consentiebat se juvare, per quod dicebant monasterium de Mormanto, Lingonensis diocesis, a domino papa fuisse sibi et ordini suo concessum, non extendabat se ad dictam domum de Nailliaco, cum non esset de membris seu pertinentiis dicti monasterii, requisivit dictos templarios quod non turbarent nec impedirent eundem episcopum vel ecclesiam Eduensem in possessionem juris sibi competentis in dicta domo, et quod exirent de loco predicto, nam quamdiu essent ibidem, non posset uti libere jure suo vel possessione juris sibi competentis ibidem, nam dicendo quod habebant administrationem et possessionem dicte domus, cujus administrationem vel possessionem nullus adipisci et habere licite, salvo
} 
The willingness of the Templars to sideline and question the supervisory authority of the bishops to which this charter testifies corresponded with a wider trend among regular religious communities in the twelfth and thirteenth centuries to resist the perceived paternalism of the bishops and to assert their independence, a trend that found additional manifestation in the creation of new parishes. ${ }^{83}$

\section{Templar Parishes}

The Templars were not only entrusted with parishes; they (and other military orders) also created them on a large scale. As many as thirty parishes in the diocese of Limoges owed their origin to the military orders. ${ }^{84}$ In fact, a recent study by Allard shows that only three of the Temple's nineteen parishes in the same diocese predated the arrival of the Templars. The remaining sixteen churches had been elevated to parochial status under the Templars, some of them

auctoritate sedis apostolice, sine consensu episcopi Eduensis, turbabant eundem episcopum et ecclesiam Eduensem in possessione juris instituendi in dicta domo rectorem et administrationem qui haberet possessionem dicte domus, et cum nollent predicti templarii acquiescere requisitioni predicte, requisivit decanum, prepositum et alios canonicos ecclesie Eduensis ibidem presentes, quod eum juvarent in deffendena licite possessione et jure ecclesie Eduensis, inhibens tamen generaliter omnibus ne quis dictis templariis vittuperationem vel injuriam inferret, nec in deffendenda possessione ecclesie modum excederet. Actum in domo de Naylliaco predicta, sub anno, indictione, mense, die et pontificatu predictis, presentibus venerabilibus et discretis viris dominis Guidone, decano, Guidone, preposito ecclesie Eduensis, Helia de Suilleyo, archidiacono Belnensi, Symone de Pontescisso, Guichardo de Combornio, Milone de Castronovo, Regnaudo dicto Buchepot, canonicis ecclesie Eduensis, Petro Mercatoris, officiali Eduensi, Johanne de Vinoma, Guillelmo de Auceyo, presbyteris, et pluribus aliis presbyteris et clericis et laycis, testibus ad hoc vocatis et rogatis. Et ego, Stephanus Gastelli, de Sancto Salvatore, clericus Autisidorensis diocesis, sacrosancte Romane ecclesie auctoritate publicus notarius, una cum predictis testibus premissis omnibus et singulis presens interfui, et in hoc instrumento publico super premissis confecto subscripsi et publicavi, signoque meo consueto signavi rogatus." $\mathrm{BN}$, n. a. l. 54, fols. 81-82 (1301).

83 The best case study on this issue is Allard, "Le côntrole des paroisses." See also Damien Carraz, "Paroisse," in Prier et Combattre (n. 1 above), 688-89. For context see Georg Schreiber, Kurie und Kloster: Studien zur Privilegierung, Verfassung und besonders zum Eigenkirchenwesen der vorfranziskanischen Orden vornehmlich auf Grund der Papsturkunden von Paschalis II. bis auf Lucius III. (1099-1181), 2 vols. (Stuttgart, 1910), 2:18-213. See also David Knowles, The Monastic Order in England, 2nd ed. (Cambridge, 1963), 600-606; Janet E. Burton, "Monasteries and Parish Churches in Eleventh- and Twelfth-Century Yorkshire," Northern History 5 (1987): 39-50; and Joseph Avril, "En marge du clergé paroissial: Les chapelains de chapellenies (fin XIIe-XIIIe siècles)," Actes des congrès de la Société des historiens médiévistes de l'enseignement supérieur public 22 (1991): 121-33. At least in Britain the Hospitallers were engaged in similar activities by the fifteenth century. See Gregory O'Malley, The Knights Hospitaller of the English Langue (Oxford, 2005), 98-99 (I thank the anonymous reviewer of this article for bringing this to my attention).

84 Michel Aubrun, L'ancien diocèse de Limoges des origines au milieu du XIe siècle (Clermont-Ferrand, 1981), 388-89. 
without the approval of the local bishop. Instead, the Templars had made use of their privilege to turn to external bishops for the blessing of their churches. ${ }^{85}$ The resulting long dispute between the cathedral chapter of Limoges and the Templars is documented in a charter dated 23 June 1282, which has been examined in detail by Allard. Linking the sixteen self-proclaimed parish churches of the Templars to their rightful mother-churches, the bishop and canons confronted the Order with a list of revenues and dues that they expected to receive from them henceforth. ${ }^{86}$

Similar complaints reached the papal curia throughout the twelfth and thirteenth centuries. One was issued by the provost and canons of Sisteron in Provence, who boycotted the Templars' plan to have an oratory erected at Sisteron for fear that this would allow them to infringe on the parochial privileges of the mother church, which belonged to the chapter of Sisteron. Innocent III's initial response was to set the canons a two-month deadline within which they could obtain a written warranty (cautio) from the Templars guaranteeing the parochial privileges of the mother church of Sisteron. If no such warranty could be produced, the Templars were permitted to finish their work on the oratory and even to build new oratories if they wished, under the condition that their building activity remained in accordance with their institutional privileges. The bishops of Avignon, Saint-Paul-Trois-Château, and Cavaillon were given the task of overseeing the implementation of the verdict. They were also given authority to subject the provost and canons of Sisteron to the judgment of the ecclesiastical court to ensure that the Templars were reimbursed for all damages and construction delays inflicted or caused by the canons. ${ }^{87}$

The precautions to protect the Order of the Temple's sacral buildings were justified by the enormous damage that groups of enraged clerics had been prone to

85 Allard, "Le côntrole des paroisses," 21. These new parishes were naturally considerably smaller than the old parishes; in Limousin their average size was 670 ha. For Templar and Hospitaller parishes elsewhere, see, e.g., Anne-Marie Legras, Les commanderies des Templiers et des Hospitaliers de Saint-Jean de Jérusalem en Saintonge et en Aunis (Paris, 1983), esp. 35 (plate).

86 Limoges, Archives départementales de Haute-Vienne, G 9 (registre $O$ Domina), fols. $70 \mathrm{v}-74 \mathrm{v}$, and G 11 (registre Tue Hodie), fols. 56v-59v. See André Lecler, ed., "Accord passé entre l'évêque de Limoges et le précepteur de la milice du Temple, relativement aux chapelles des Templiers dans le diocèse de Limoges, 23 juin 1283," Bulletin de la société archéologique et historique du Limousin 54 (1904): 493-503 for a full edition of the agreement; and Jean-Marie Allard, "Templiers et hospitaliers en Limousin au Moyen Âge: État de la recherche et nouvelles considérations," Revue Mabillon, n.s., 14 (2003): 71-77, for a partial edition. See also Jean-Marie Allard, "L'accord de 1282 entre l'évêque de Limoges et le précepteur du Temple en Limousin," Bulletin de la Société archéologique et historique du Limousin 129 (2001): 23-44. Whether or not the accord reached in this charter actually reversed the situation in the diocese to the status quo ante I do not know; but I think it unlikely since all contested new parishes were by the fifteenth century in the possession of the Hospital.

87 Die Register Innocenz' III., ed. Othmar Hageneder and Anton Haidacher, 7 vols. (Graz and Cologne, 1964- ), 7:163-64, no. 101 (1204). 
inflict upon Templar communities on other occasions. A few years earlier, for example, the pope had excommunicated the prior and monks of Saint-Pourçain in Auvergne and put their community under interdict for the vicious attack they had conducted one Good Friday on a nearby Templar church, which had cost the Templars more than fifty marks in fire damages and had left them with one brother injured and their altar smashed into pieces. As so often, the attack had escalated from a dispute over tithes and burial fees, which the monks had accused the Templars of exacting and withholding unlawfully. ${ }^{88}$

The legates whom the papacy dispatched to mediate in these conflicts did not always decide in favor of the Templars, however. A legal complaint issued by the canons of Maguelonne and concerning the Templars of Montpellier's collection of tithes, oblations, and vigil and burial fees, but equally the establishment of new church buildings and the issues of inflicted violence and perceived injustices, was settled by the papal legate Archbishop Imbert of Arles. His verdict required of the Templars that they share their revenues with the canons of Maguelonne and the prior of Saint-Firmin. They were ordered to desist from constructing further churches or oratories in the diocese of Maguelonne without prior consent of the bishop and chapter and were forced to destroy their chapel at Lunel, which they had already started building. They were no longer to accept excommunicates or anyone put under interdict by the church of Maguelonne into their church or for burial in their cemetery, misconduct of which they seem to have been guilty in the past. What is more, henceforth, whenever the bishop or the prior of the parish church called for the parishioners of other churches to congregate, the Templars were prohibited from celebrating the offices with the laity in the presence of parishioners from other churches. The canons, alternatively, were henceforth expected to leave the other possessions of the Templars in peace and to work towards an agreement on how the grievances caused by the damages and injustices they had inflicted on the Templars and the repeated attacks on their property, during which the canons had abducted some of the Templars' farm animals, could be settled. ${ }^{89}$

The battle over church control - or better, the control of church revenues and exercise of the pastoral activities from which these derived - to which these accounts testify, is indicative of the quagmire of conflicting loyalties and authorities into which Templar parishes could be drawn. In particular, on important feast days, the spurned mother churches commended themselves to the parishioners by insisting on legal, traditional, and customary obligations. We can use the Limoges charter of June 1282 mentioned earlier as a window into an ideal image of the past as created by the bishop and his canons, and, if we do, we see

\footnotetext{
88 Register Innocenz III., 5:265-69, no. 135 (1202).

89 BNF, n. a. 1. 15, fols. 61-66 (1196); Register Innocenz III., 1:737-41, no. 507 (1198).
} 
that, on the day after Easter, the parishioners of the small Templar church of La Forest were expected to march in procession to the nearby church of Nouziers to make pious oblations there. The parishioners of the Templar chapel at Poulhat were expected to meet once a year at the feast day of St. Stephen for a procession to the church dedicated to the saint at Fursac, as was customary; and their contemporaries from the new Templar parish of Chambon were expected to gather on the day after Pentecost to walk in procession to the church of Chirac for their payment of their annual oblation of one denar. ${ }^{90}$ However, in many dioceses this ideal image was in the past. Under the Templars the chapels had become parish churches in their own right, which means that the Order had equipped them with an altar and a baptismal font or that they had been subjugated to a parish church under Templar patronage. They were served by clergy who had not necessarily been approved by the bishop and over which he had in practice often only limited disciplinary power.

Clashes between the Templars and other church bodies occurred when the Templars began sidelining the authority of senior ecclesiastics by elevating the status of their chapels to that of parish churches without the bishops' prior consent and with little regard for the rights of other communities or the established relationships of these chapels with existing parish churches. ${ }^{91}$ Their actions were partly motivated by the heightened public demand for new spiritual advocates, which is reflected in the general success of the new reformed religious orders. ${ }^{92}$

\section{Templars and Cura Animarum}

For the bishops and prelates, the unchecked spread of pastoral activity through new and increasingly autonomous religious institutions like the military orders, but not only through them, posed a serious threat to their own authority over cura animarum..$^{93}$ The bulls issued by Pope Alexander III condemning the celebration of mass in the parish without prior consent of the bishop are as much a testament to that threat as are the decrees of Lateran III (1179) insisting on the

90 Allard, "Templiers et hospitaliers en Limousin," 72-74

91 On the use of parishes in the military orders see Carraz, "Paroisse," 688-89. For evidence that the Templars made use of parish churches, see, e.g., Richard Gem, "An Early Church of the Knights Templars at Shipley, Sussex," in Anglo-Norman Studies, vol. 6, Proceedings of the Battle Conference 1983, ed. Reginald A. Brown (Woodbridge, 1984), 238-46, at 240.

92 In 1211, for example, parishioners of San Fiorenzo in Fiorenzuola petitioned for papal permission to attend divine office in the church of the Templars; three years later they were granted permission to choose burial in the Templar church of Santa Margherita. Bellomo, Templar Order in Italy (n. 31 above), 152.

93 Toulouse provides a good case in point. See John Mundy, "The Parishes of Toulouse from 1150 to 1250," Traditio 46 (1991): 171-204, at 177-80; and generally Constable, Reformation (n. 57 above), 246-49. 
presentation of parish priests to, and their reception by, the bishop. ${ }^{94}$ Complaints that were brought before the church courts and the papal curia often centered on the same issues: the Templars were practicing their parochial duties illegally and had taken away burials from the parish churches, or they were (perceived to be) threatening to do so once a particular chapel had been built; and they were withholding parish revenues. ${ }^{95}$ Elena Bellomo has unearthed many such cases for northern Italy. In 1186, for example, Urban III issued a stern warning against the Templars in Acqui to stop administering pastoral functions for parishioners of other religious institutions in the city, and in 1217 Honorius III issued a similar warning against the Order's priests in the city of Alba to stop blessing pilgrims" purses and admitting "sponsas vel paiolatas levantes de partu vel surgentes" to the mass. ${ }^{96}$ Similar grievances strained relations between the military orders and secular clerics in urban centers in Provence, as Carraz has shown. ${ }^{97}$ The Templars of Arles and Saint-Gilles were by 1217 in conflict with the archbishop and canons of Arles over tithes in Argence, which they were then receiving from possessions in the diocese of Arles, and from revenues that they had been drawing from last wills and to which the archbishop and his canons claimed entitlement. Eventually the parties met in the cloisters of Saint-Trophime and a compromise was reached, which demanded of the Templars fixed yearly payments to the archbishop and canons of Arles and the transfer to the canons of the fourth part of all deathbed bequests made by parishioners from the diocese of Arles who had chosen their burial with the Templars, with the exception of horses, mules, and arms ("exceptis equitaturis, scilicet destrariis, roncinis, mulis et mulabus et armis"). Also not affected were donations made to the Templars inter vivos, to which the canons and archbishop had no legal claim. The Templars were prohibited from administering the divine office for excommunicates or for people put under interdict by the church of Arles, which indicates that they had done so in the past. The ruling also suggests, however, that the general prohibition against accepting parishioners in the church without formal approval by the bishop had been lifted. The Templars were still not allowed to receive excommunicates and persons under interdict as brothers or donats into their communities, but parishioners from Arles were henceforth free to choose their burial with them. ${ }^{98}$

94 Joseph Avril, "Églises paroissiales et chapelles de châteaux aux XIIe-XIIIe siècles," in Seigneurs et Seigneuries en Moyen Age: Actes du 117e congrès des sociétés savantes, ClermontFerrand, 1992; Section d'histoire médiévale et de philologie (Paris, 1993), 471-79, at 466.

95 See, e.g., José de la Canal, "Iglesias de Lérida, Roda y Barbastro," España sagrada 46 (1836): 398-400 (1192).

96 Bellomo, Templar Order in Italy, 152.

97 Carraz, L'ordre du Temple (n. 1 above), 326-27, 463-69.

98 Marseille, Archives départementales des Bouches-de-Rhône, 3 G 10 ("Chartrier de Salon”), no. 369 (Carraz, Ordres militaires, croisades et sociétés méridionales, 3:108-10, "Chartes de la maison du Temple d'Arles," no. 66) (1217). 
It is from these and similar accusations leveled against the Templars by the bishops and prelates that examples of the Templars' pastoral work in the parish and in society at large can be drawn. As has been seen, usually the accusations concerned the illegal administration of the divine office and the celebration of mass and the sacraments for non-associated members of the lay public, activities that often went hand in hand with the Templars' endeavor to transform smaller chapels into parish churches. In 1260, the bishop of Auxerre issued a formal complaint at the papal curia that the local Templars had given their chapel at Monteau the exterior of a parish church, that they were regularly ringing the bell to summon people for mass, and that they were celebrating marriages in the church. ${ }^{99}$ Accusations like these were not without foundation. In fact, a number of manuals, office books, and liturgical instruments found in Templar churches and recorded in the inventories testify to a variety of pastoral activities, not all of which the Templars would have performed unlawfully. The books discovered in the Templars' church of Grasse in Provence during the investigation of Templar property following the arrest of the Templars in 1307 included one ritual on the baptism of children; ${ }^{100}$ those discovered at Ormelle in Treviso and San Vitale in Verona included rituals on religious instruction ("cathecuminos faciendos; liber ad faciendum christianos") and, in the case of San Vitale, exorcism (incipit Exoçiço te) ${ }^{101}$ and those discovered in the Templar church of Santa Maria in Bologna included another ritual on how to make holy water for the sick, ${ }^{102}$ all of which suggest a localized involvement of Templar clergy in pastoral activity.

The precautions undertaken by the prelates to maintain control over Templar pastoral activities and their outcry when they felt the Templars had infringed on their authority are indicative of the increasing popularity of the Templars as providers of spiritual advocacy in the late twelfth and thirteenth centuries; this popularity was concomitant with a rise in demand for burial in the Order's cemeteries,

\footnotetext{
99 Lavirotte, "Mémoire statistique" (n. 72 above), 273.

100 "Unum librum in quo est scriptum officium quod dicitur quando baptizantur infantes." Aix-en-Provence, Archives départementales des Bouches-de-Rhône, B 433 ("Chartes de la Tour du Trésor"), no. 2 (1308). See also Prutz, Entwicklung und Untergang (n. 27 above), 343; and Anne-Marie Legras and Jean-Loup Lemaître, "La pratique liturgique des Templiers et des Hospitalliers de Saint-Jean de Jérusalem," in L'écrit dans la société médiévale: Divers aspects de sa pratique du XI au XV siècle; Textes en hommage à Lucie Fossier, ed. Caroline Bourlet and Annie Dufour (Paris, 1991), 77-137, at 124. A more detailed discussion of these and similar books can be found in Jochen Schenk, "The Documentary Evidence for Templar Religion," in The Templars, Their Sources and Their Competitors (1119-1314): Die Templer (1119-1314); Bilanz und Perspektiven der Forschung, ed. Karl Borchardt, Helen Nicholson, and Philippe Josserand (Farnham, forthcoming).

101 Renzo Caravita, "Nuovi documenti sull'ordine del Tempio dall'Archivio Arcivescovile di Ravenna," Sacra militia 3 (2002): 225-78, at 255 (Ormelle, 1310) and 262-63 (San Vitale, 1310). 102 Appendice al Monumenti Ravennati dei Secoli di Mezzo del Conte Marco Fantuzzi, ed. Antonio Tarlazzi, 2 vols. (Ravenna, 1869-76), 1:502-3, no. 325:2.
} 
which is also supported by archaeological evidence, ${ }^{103}$ and which in turn was closely related to a rise in confraternity agreements. At the core of any confraternity agreement, and arguably behind many professions, lay the desire to be buried within the sacred space of a chosen religious community, which would also be chiefly responsible for the commemoration of the deceased's soul.

Also closely linked with the desire for burial was the personal but also very public desire for memoria, the commemoration of the dead through the prayers of the living. This was another activity in which the Templars, through their churches, were actively engaged and for which they were approached by outsiders. Around individual commanderies and their churches, confraternities developed. Focused as they were on commemoration, these prayer communities played an important part in promulgating a sentiment of attachment to the Order among parishioners, in particular if they included the local clergy, as was the case at Templar Cardington in Shropshire in 1185, where the local Templar confraternity included not only the vicar of the church but also the local priest and his wife. ${ }^{104}$ The charters and testaments from the twelfth and thirteenth centuries contain evidence that laymen and -women trusted the Templars with the business of cura animarum, which the Templars were expected to provide with the help of secular priests especially employed for this task. Already before 1151, for example, Lady Amultrudis reacted to her concerns for her spiritual well-being and that of her ancestors by promising part of her possessions to the Templars of Laon if they would use it to employ one of their own or a hired priest to celebrate the divine offices, "as it becomes a house of the Lord," in the order's church of Sainte-Genovefe. ${ }^{105}$ At around the same time, a certain Deusde Gat and his wife Estolz gave the church of Routlac to the Templars of La Selve in Aveyron, expecting that the Templars would from now on "sing mass and matins at La Selve and visit the cemetery at the day of the Invention of the True Cross," where Deusde also asked to be buried. ${ }^{106}$ In 1195 , Uc Sacristain

103 See, e.g., Nelly Posthoumis-Dalle, "Histoire et archéologie de la commanderie-grandprieuré des hospitaliers de Saint-Jean à Toulouse: État de la recherche," in Les ordres militaires dans le Midi, ed. Julien Théry, Cahiers de Fanjeaux 41 (Toulouse, 2006), 239-64, who, however, concerns herself only with the Hospitallers.

104 Lees, Records (n. 43 above), cvii; Licence, "Military Orders" (n. 1 above), 48.

105 "Itaque notum fieri volumus tam presentibus quam futuris quod domina Amultrudis, de sua suorumque predecessorum salute religiose cogitans, quedam bona, que libere ac quiete possidebat, ad usus sacerdotis, qui in Templo, quod est in civitate Laudunensi, non longe ab ecclesia Sancte Genovefe situm, divina ministeria celebraturus constitueretur, ut ipsa templum Domini fieri mereretur, Deo et Templo devote contulit, ita tamen quod, si fratres Templi Hierosolimitani aliquem de suis fratribus aut sacerdotem alium, expensis suis, ibidem cantare fecerint, beneficia, que iam dicturi sumus, eterno jure possidebunt." Actes des évêques de Laon des origines à 1151, ed. Annie Dufour-Malbezin (Paris, 2001), 458-59, no. 318 (c.1129x51).

106 "Cantar mesa et matinas à la Selve e revidem lo cementeri (al) die Inventio Ste Crucis." Du Bourg, Histoire du grand-prieuré (n. 6 above), lxix, no. 103 (1150). 
sold to the Templars of Saint-Gilles extensive properties and in return received assurance, in the presence of the archbishop of Arles, that his kin (parentes) and friends would henceforth be commemorated by the Templars, that a priest of the house would chant a special prayer for them every day, and that after his death the priests of the house would chant masses every year to celebrate his anniversary. ${ }^{107}$ When in January $1223 \times 24$ a certain John Rufus elected the Templar cemetery of Arles as his place of burial, he bequeathed to the Templars not only 1,200 sous, parts of his landed possessions, and a vineyard, but he also ordered that the Templars should receive the sum of 200 sous to allow one secular priest (sacerdos) for one year to celebrate the divine office for his soul and that of his late nephew William Peter. ${ }^{108}$ When Count William of Joigny felt his end approaching, in July 1238, he made arrangements in his testament that, for the benefit of his soul and the souls of his ancestors, a chapel should be erected in the Templar commandery of Saulce-sur-Yonne, for which his family had been acting as patrons for almost fifty years, and which he hoped to make sustainable with a perpetual endowment of fifteen livres turnois payable every year in three installments (300 sous each) at the Octave of All Saints, the Octave of the Purification of Mary, and the Octave of the Ascension. ${ }^{109}$ In 1243, the nobleman Barral of Baux acted on his heartfelt concern for the spiritual well-being of his deceased parents by promising the Templars of Arles enough material provisions to pay for the employment of another priest (sacerdos) for the perpetual care of his parents' souls. ${ }^{110}$ In 1259, Berenguer of Catena made concessions to the commandery of Arles to have his and his parents' anniversaries celebrated by the brothers. ${ }^{111}$ In 1264, Bertran Rainouart chose the same commandery as his and his father's final resting place and promised the Templars a piece of land if they agreed to

107 "Recipio te in beneficiis domus nostre et animas parentum tuorum et omnibus amicorum tuorum et pro te et illis specialem orationem sacerdotem domus nostre Deo cotidie cantare faciam, et post obitum tuum die anniversari tui, singulis annis, pro anima tua sacerdotes domus nostre missas cantare curabo." Arles, Archives municipales, GG 87, no. 2 (Damien Carraz, Ordres militaires, croisades et sociétés méridionales, 3:578-79, "Chartes de la maison du Temple de Saint-Gilles, “no. 288) (1195).

108 Marseille, Archives départementales des Bouches-de-Rhône, 56 H 5175 (Carraz, Ordres militaires, croisades et sociétés méridionales, 3:116-17, "Chartes de la maison du Temple d'Arles," no. 77 (copy, 12/10/1228).

109 AN S 5237, dossier 30, no. 5 (1238).

110 Marseille, Archives départementales des Bouches-de-Rhône, 56 H 5184 (Carraz, Ordres militaires, 3:151-52, "Temple d'Arles," no. 119) (1243).

111 "Item lego domui milicie Templi Arelatensis pasturas meas dels Leols, quas teneo sub dominio dominorum de Fos, ita quod fratres dicte domus teneantur facere adniversarium (sic) singulis annis, die obitus mei pro anima mea et parentum meorum." Marseille, Archives départementales des Bouches-de-Rhône, 56 H 5182 (Carraz, Ordres militaires, 3:165-67, "Temple d'Arles," no. 136) (1259). 
celebrate his anniversary in their church in Arles. ${ }^{112}$ Guy of Toucy ensured the commemoration of his anniversary in the Templar church of Saulce-sur-Yonne with similar concessions in 1268. ${ }^{113}$ And still in August 1299, Isabel, the widow of William of Grancey, whose family had been ardent supporters of the commandery of Bure for more than one and a half centuries, endowed Bure with a house and chapel in Courcelles under the condition that the chapel would remain active and that her own anniversary and that of her late husband would be celebrated at Bure. ${ }^{114}$

People who had arranged for votive masses and masses for the dead in churches that later came under Templar patronage could expect the Templars to honor these arrangements and provide the requested services. The continuing commemoration of benefactors, living or dead, and their relatives in churches that had subsequently come into the Order's possession enabled the Templars to weave local traditions into their devotional practices, thus adding clout and substance to their own religious standing in the region. The obituary of La Trinité in Reims is a good case in point. Formerly home to a chapter of canons, the collegial church La Trinite had, by 1170 , come into the possession of the Templars. ${ }^{115}$ Recorded in the obituary of La Trinité, which forms part of a necrological manuscript that the Templars had inherited with the church and that they had decided to continue, were the names and anniversaries of more than three hundred men and women for whose souls the Templars of La Trinité had agreed to pray, including the names and anniversaries of former canons of La Trinité and of many of the canons' lay associates, whose donations and rents had secured them chantry masses and prayers of commemoration at the church's altars. ${ }^{116}$ Over the course of the thirteenth century the Templars made additions to the obituary and the martyrology also embedded in the manuscript, thus creating, as

112 "In primis eligo michi sepulturam in cimiterio domus Templi, una cum domino pater meo condam. Et accipio pro anima mea xx solidos quos volo distribui piis locis et causis arbitrio gadiatorum meorum. Item lego domui Templi quemdam terram que est in Triboncio que terra confrontatur ex una parte terre domus Templi et ab alia terre Benedicti Baconi pro anniversario meo singulis annis faciendo in ecclesia dicte domus pro anima mea." Marseille, Archives départementales des Bouches-de-Rhône, 56 H 5177 (Carraz, Ordres militaires, 3:177-78, "Temple d'Arles," no. 145).

113 "Et ob remedium anime mee et antecessorum meorum, et pro anniversario meo in ecclesia de Salice super Yonam anno quolibet post decessum meum faciendo terciam partem circiter quadraginta libratarum annui redditus." AN S 5238, dossier 41, no. 2 (1268).

114 Dijon, Archives départementales de Côte-d'Or, carton 111 H 1156, Fonds de Bure, no. 1 (1299). The involvement of the lords of Grancey with Templar Bure is illustrated in Schenk, Templar Families (n. 1 above), 141-46.

115 Obituaire Reims (n. 10 above), 330 for the entry on Archbishop Henry of Reims.

116 For canons of La Trinité commemorated in the obituary, see Obituaire Reims, 314, $315,316,318,319,321,325,328,329$. The tradition of La Trinité also linked the Templars with other religious communities in the city and in particular with the cathedral chapter of Our Lady of Reims. See, e.g., ibid., 314, 315, 319, 321, 323, 325, 330, 332. 
Michael Peixoto has shown, a symbolic connection with the church's former occupants and their patronage network. ${ }^{117}$

\section{Conclusion}

The military orders were the most radical expression of a spiritual development in the twelfth and thirteenth centuries that favored action over contemplation. ${ }^{118}$ Public engagement, for example, through charitable work, could form part of these activities, although for the Templars it never became an end in itself. The rule of the Order of the Temple clearly favored an introspective spiritual development through outward action guided by right intentions. ${ }^{119}$ This means that although they engaged in the world, the Templars' motivation for doing so was ultimately self-centered and in line with Cistercian ideas of inward spiritual edification. Consequently, the Templars were strongly discouraged from celebrating the offices in the company of laymen. ${ }^{120}$ And parishioners who entered churches under Templar patronage would therefore seldom have encountered professed Templar brothers practicing their devotion. Moreover, because the number of professed priests in the Order of the Temple was never sufficient, church benefices, as has been seen, were frequently given to outsiders who had been hired by the Order to help cope with the increasing demand for requiem masses and vigils. ${ }^{121}$

This, however, is not to say that laymen and laywomen were not aware that the Templars had a religious presence, and were religiously active, in their parishes. Like other religious communities, the Templars marked their ecclesiastical possessions and decorated their devotional spaces with their insignia, usually the Templar cross. The Templars' activities brought them into frequent contact with laypeople and ecclesiastics alike, who visited their churches, associated with them temporarily, helped them through the liturgical routine of the year, or sought spiritual assistance

117 Peixoto, "Maintaining the Past, Securing the Future" (n. 10 above), esp. 226-30.

118 Luis García-Guijarro Ramos, "Ecclesiastical Reform and the Origins of the Military Orders: New Perspectives on Hugh of Payns' Letter," in The Military Orders, vol. 4, On Land and by Sea, ed. Judith Upton-Ward (Aldershot, 2008), 77-83.

119 On this topic, see in particular the research by Simonetta Cerrini, especially "I templari: Una vita da fratres, ma una regola anti-ascetica; Una vita da cavalieri, ma una regola anti-eroica," in I Templari, la Guerra e la Santità, ed. Simonetta Cerrini et al. (Rimini, 2000), 19-48; and eadem, La révolution des templiers: Une histoire perdue du XII siècle (Paris, 2001), esp. $135-62$.

120 Hiestand, Papsturkunden (n. 7 above), 1:204-10, no. 3.

121 See, e.g., "in primis eligo sepulturam in cimiterio Beate Marie de milicia et accipere pro anima mea II. milia et CC. sol. et terram meam et vineam que sunt in Trebo(n)cio, et dictam terram et vineam relinquo domui milicie Arelatis. Item, relinquo eidem domui milicie CC. sol(idos) pro tenendo unum sacerdotem in ecclesia ejusdem domus per unum annum, q(ui) celebret divina pro anima mea et pro anima Guil(e)l(m)i Petri, quondam nepotis mei." BNF, n. a. 1. 7, fols. 137-39 (1223x24). 
and advocacy. Some criticism was voiced about the fact that the Templars, as professed members of a religious order, engaged in military activities, and opinions differed on how a spirituality thus expressed compared to that of more traditional religious institutions. ${ }^{122}$ In spite of the fundamental skepticism regarding the spiritual worth of Templar activities, however, the religiosity of the Temple itself was never questioned. Popes, bishops, and prelates entrusted the Order with spiritual responsibilities and religious duties and interfered if they thought the Templars were overstepping or abusing their privileges. But they never argued that the Order was fundamentally unfit to perform them.

Nor should the introspective spirituality of the Templars (at least as described in the normative documents) distract from the fact that, at the local level, the Order seems to have been quite keen to expand its religious presence and engage with laymen. The inventory lists of Templar houses and the accounts of lawsuits and complaints issued by other religious suggest that religious activity was taken seriously in the Temple and that considerable energy was spent on the creation of devotional spaces that Templars as well as laymen could use. Recent research into the liturgical inventories of Templar chapels and churches has shown that a number of these spaces (especially in Spain) allowed for carrying out a variety of liturgical tasks in an environment and visual context that was often laden with color and symbolic meaning. ${ }^{123}$ What the present study has shown is that the churches and chapels secured the Order a place on the religious map of medieval Europe and that in France, England, and the Iberian Peninsula at least, the Templars pursued the opportunities offered by these places to engage with the wider public and create parishioners quite aggressively, to such an extent that they have been described as "agents of civic religion." 124

\section{University of Glasgow}

Keywords: Military Orders, Order of the Temple, Templar religion, medieval parish, religious reform

122 Helen Nicholson, Templars, Hospitallers and Teutonic Knights: Images of the Military Orders, 1128-1291 (London, 1993).

${ }^{123}$ On which see, e.g., Sebastián Salvadó, "Templar Liturgy and Devotion in the Crown of Aragon," in On the Margins of Crusading: The Military Orders, the Papacy and the Christian World, ed. Helen J. Nicholson (Farnham, 2011), 31-44; and Schenk, "The Documentary Evidence" (n. 100 above).

124 Carraz, "Templars and Hospitallers in the Cities," 114. That this may not have been a universally adopted policy is suggested by Maria Starnawska's recent observation that in Poland the Templars did not seem to have made much use of their churches at all. See Maria Starnawska, "Zur Geschichte der Templer in Polen," Regionalität und Transfergeschichte: Ritterorden-Kommenden der Templer und Johanniter im nordöstlichen Deutschland und in Polen seit dem Mittelalter, ed. Christian Gahlbeck, Heinz-Dieter Heimann, and Dirk Schumann (Berlin, 2014), 47-62, esp. 59. 